International Journal of Recent Advances in Mechanical Engineering (IJMECH) Vol.7, No.1/2, May 2018

\title{
ANALYsis THe Residual StRESS IN Single PoINT CutTINg TOOL DURINg TuRning OPERATION ON AISI 1006: FEM AND ARTIFICAL NEURAL NETWORK METHODOLOGY
}

\author{
Amber Batwara \\ Mechanical Department, Poornima College of Engineering \\ Jaipur, Rajasthan-302037, India
}

\begin{abstract}
Residual stresses generated in tool play a very important role during machining process .The functional behavior of tool can be enhanced or affected by residual stresses. To understanding the residual stress imparted by machining is an important aspect of the overall quality of the part. The main objectives of this paper is develop a numerical approach to predict the near surface residual stresses in cutting tool and work piece resulting from turning of AISI 1006 and validate the model with ANN. The FEM Explicit dynamics is used for calculating the residual stress in real time environment. Total L16 experiments were designed by Taguchi method. Three input factors (depth of cut, cutting speed and rack angle) and two responses (stress and strain) selected for simulation work. Optimizations of process parameters were done using design of experiments (DOE) and analysis of variance (ANOVA) for some qualitative outcome. In this study model equations are also generated for further analysis using linear regression modeling technique using Minitab software. An artificial neural network model is using for the analysis and prediction the responses. On the basis of simulation work tool wear is dependent on rack angle.
\end{abstract}

KEYWORDS

Artificial Neural Network, ANOVA, DOE, FEM, Modal equation.

\section{INTRODUCTION}

Simulation can increase the understanding of the cutting process and reduce the number of experiments. Researchers find these variables by using experimental techniques which makes the investigation very time consuming and expensive [5]. At this point, finite element modeling and simulation becomes main tool. These important cutting variables like stress and strain can be predicted without doing any experiment with finite element method. This paper present a attempt to use the finite element simulation of the turning process using single point cutting tool for realistic and comprehensive modeling of effect of operational parameter which also include all non linear effects that are present in cutting process .Today finite element method and the simulation becomes the main tool. The finite element method is used to simulate the cutting conditions at which the dynamic instability may be occurring and the interaction between two phenomena is studied [6].It is also found that it is the most realistic modeling of cutting process which is able to include various phenomena in chip formation can be obtain by numerical simulation of cutting process.

It should be noted that the accuracy of Finite Element modeling is determined by how adequately the characterization of selected input parameters reflect the deformation behavior undergoing during the chip formation in the actual practice. In general the application of finite element modeling for cutting process involves consideration of certain key features such as type of formulation, material models, friction models and chip separation criterion. Langrangian 
formulation is easy to implement, efficient and fast converging but unable to handle large deformation problems involving high mesh distortion

\section{Numerical Simulation AND Problem Identification}

FEM has become a powerful tool in the simulation of cutting process such as cutting force, cutting temperature, stress, strain, cutting speed and depth of cut. In the recent years there have been increasing attempts to extend the finite element method techniques to cutting with non sharp tools. The Finite Element Method simulation is used for conventional machining process and it predict the chip formation, strain rate and stress on the cutting edge. Simulation substitute the expensive and time consuming experimental tests for predicting measure variables such as stress, strain and machining temperature. It also determines result with higher accuracy as compared to the any analytical models. The first model was developed for metal cutting process by Klamecki in the year 1972. After that many works has been done by using FEM for gaining better result of the machining process.[10]

Explicit dynamics analysis is used to determine the dynamic response of structure and in the static implicit methods used for simulation, static equilibrium is satisfied in the unknown final configuration of a time increment. In this method convergence control is used for determining a full static solution to the problems with deformation. Theoretically very large increment sizes can be selected throughout the process, but contact conditions in the problem limit the size of increments, so small enough increments are selected. As the element number increases, computational time increases as well. Required memory for the problem is also high because of matrix inversion step with accurate integration process. The most important disadvantage of implicit method is the divergence problem.

In this study two engineering materials were used for analysis from them one was used by work piece was used by plate (SS-304) and another for tool steel 1006. Table 1 to 2 show properties of materials .

Table 1 Properties of structural Steel (used for Tool)

\begin{tabular}{|c|c|c|}
\hline Property & Value & Unit \\
\hline Density & 7850 & $\mathrm{Kg} / \mathrm{m} 3$ \\
\hline Young's Modulus & $2 \mathrm{E}+11$ & $\mathrm{~Pa}$ \\
\hline Poisson's Ratio & 0.3 & \\
\hline Bulk Modulus & $1.66 \mathrm{E}+11$ & $\mathrm{~Pa}$ \\
\hline Shear Modulus & $7.692 \mathrm{E}+10$ & $\mathrm{~Pa}$ \\
\hline Sp. Heat & 434 & $\mathrm{~J} / \mathrm{kg} \mathrm{C}$ \\
\hline
\end{tabular}

Table 2 Properties of Steel AISI 1006

\begin{tabular}{|c|c|c|}
\hline Property & Value & Unit \\
\hline Density & 7896 & $\mathrm{Kg} / \mathrm{m} 3$ \\
\hline Sp. Heat & 452 & $\mathrm{~J} / \mathrm{kgC}$ \\
\hline Initial Yield Stress & & \\
\hline Hardening Constant & $3.5 \mathrm{E}+08$ & $\mathrm{~Pa}$ \\
\hline Hardening Exponents & $2.75 \mathrm{E}+08$ & $\mathrm{NA}$ \\
\hline Strain rate constant & 0.36 & $\mathrm{NA}$ \\
\hline Thermal softening exponent & 0.022 & $\mathrm{NA}$ \\
\hline Reference Strain Rate & 1 & $\mathrm{NA}$ \\
\hline Melting Temperature & 1 & $\mathrm{NA}$ \\
\hline Shear Modulus & 1537.9 & $\mathrm{C}$ \\
\hline Shock EOS Linear & $8.18 \mathrm{E}+10$ & $\mathrm{~Pa}$ \\
\hline Gruneisen Coefficient & & \\
\hline Parameter C1 & 2.17 & $\mathrm{NA}$ \\
\hline Parameter S1 & 4569 & $\mathrm{~m} / \mathrm{s}$ \\
\hline Parameter Quadratic S2 & 1.49 & $\mathrm{NA}$ \\
\hline & & $\mathrm{s} / \mathrm{m}$ \\
\hline
\end{tabular}


In this study orthographic material properties were used so that FEM results are predicted more perfectly with real world environment. Tool material is only elastic material and this problem can resolve by converting it to dynamic body. Impact analysis was dependent on equations of state of materials and here these equations were used for accurate simulations of impact (Impact of tool on plate), these equations were used for change of states of material after impact and simulate effect of impact like impact of tool and solution after tool impact on plate was shown clearly.

Table 3 Summary of all levels and their factors

\begin{tabular}{|c|c|c|c|}
\hline $\begin{array}{c}\text { Factor/ } \\
\text { Level }\end{array}$ & Cutting Speed (m/min) & Depth of cut (mm) & Rake Angle \\
\hline 1 & 100 & 0.25 & 0.0 \\
\hline 2 & 125 & 0.50 & 2.0 \\
\hline 3 & 150 & 0.75 & 4.0 \\
\hline 4 & 200 & 1.00 & 6.0 \\
\hline
\end{tabular}

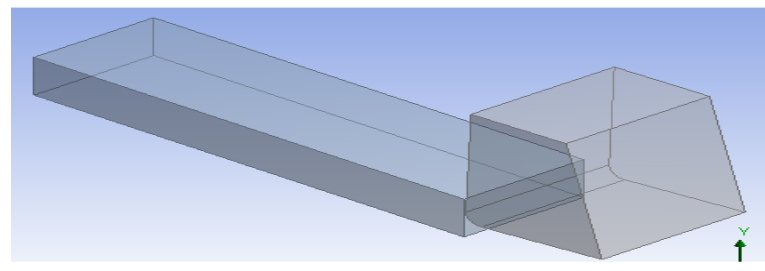

Fig. 1 CAD design of Test Plate and Tool

\section{DESIGN Of EXPERIMENT AND RESEARCH METHOdOLOGY}

Design of Experiments (DOE) is a methodology for systematically applying statistics to experimentation. It estimates the effect of each variables on the response are more effectively and precise. It can creating, analyzing, and plotting experimental designs and improve the process. It is consists a series of no. of experiments which purpose is doing some changes in the input variables (factors) of a product or process, after may be observe and identify the reasons for these changes in the output response. DOE can screen the factors to determine which are important for explaining process variation, after screen the factors, Minitab helps to understand how factors interact and drive the process. It provides a cost-effective and quick method to understand and optimize products and processes. Designed experiments are often carried out in four phases: planning, screening, optimization, and verification.

Figure 2 represents a flow diagram, which describe all steps involved during simulation to data collection. Statistical analysis of this study is done using Minitab software. All steps involved for DOE analysis are following: 
International Journal of Recent Advances in Mechanical Engineering (IJMECH) Vol.7, No.1/2, May 2018

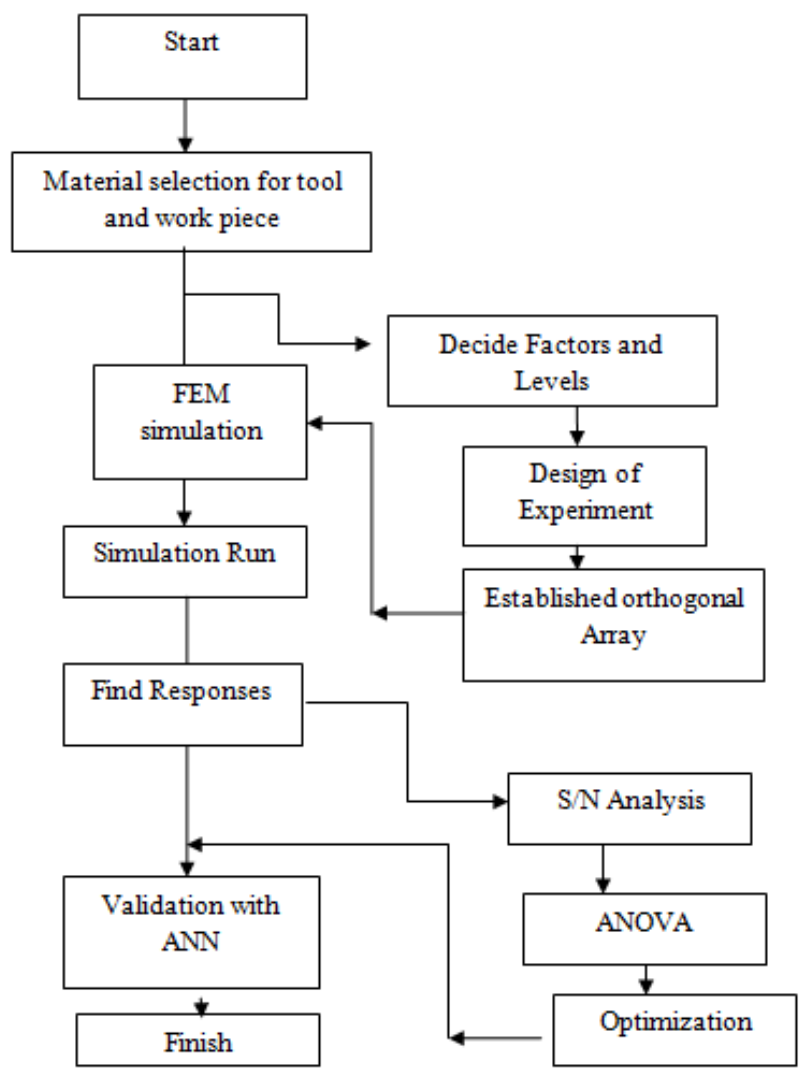

Fig. 2 Simulation flow chart

Available DOE table is L16 for AISI 1006. These materials are used in this study for cutting operation. Relief angle and nose radius is constant for this study. Tool stress and work piece studied in this paper.

Table 4. 16 Experiments According DOE Surface Response

\begin{tabular}{|c|c|c|c|}
\hline Sr. No. & Cutting Speed (m/min) & Depth of cut (mm) & Rake Angle \\
\hline 1 & 100 & 0.25 & 0 \\
\hline 2 & 100 & 0.50 & 2 \\
\hline 3 & 100 & 0.75 & 4 \\
\hline 4 & 100 & 1.00 & 6 \\
\hline 5 & 125 & 0.25 & 2 \\
\hline 6 & 125 & 0.50 & 6 \\
\hline 7 & 125 & 0.75 & 4 \\
\hline 8 & 125 & 1.00 & 4 \\
\hline 9 & 150 & 0.25 & 6 \\
\hline 10 & 150 & 0.50 & 0 \\
\hline 11 & 150 & 0.75 & 6 \\
\hline 12 & 150 & 1.00 & 4 \\
\hline 13 & 200 & 0.25 & 2 \\
\hline 14 & 200 & 0.50 & 0 \\
\hline 15 & 200 & 0.75 & \\
\hline 16 & 200 & 1.00 & \\
\hline
\end{tabular}


International Journal of Recent Advances in Mechanical Engineering (IJMECH) Vol.7, No.1/2, May 2018

\section{RESUlt AND DisCUSSION}

Single point cutting process is simulated in this study for one design cases which is shown in figure 1. ANSYS Explicit Dynamics FEM package is used for simulation purpose. All experiments were designed according to DOE technique (Taguchi orthogonal array table), which were presented table 4 . Main outcomes focused in this study are following:

- Signal to noise ratios analysis

- ANOVA Analysis

- Model equations generation

In this study response is von-misses stresses (MPa) developed during cutting process is selected, and all results according to L16 array experiments is presented in table 5.

Table 5.Response result from FEM code simulation

\begin{tabular}{|c|c|c|c|c|c|c|c|}
\hline Sr. No. & cutting speed & Feed Rate & Rake Angle & $\begin{array}{c}\text { Stress } \\
\text { in } \\
\text { Work } \\
\text { piece }\end{array}$ & $\begin{array}{c}\text { Strain } \\
\text { in } \\
\text { Work } \\
\text { piece }\end{array}$ & $\begin{array}{c}\text { Stress } \\
\text { in Tool }\end{array}$ & $\begin{array}{c}\text { Strain in } \\
\text { Tool }\end{array}$ \\
\hline 1 & 250 & 0.6 & 0 & 578.77 & 1.1835 & 827.6 & 0.0052181 \\
\hline 2 & 250 & 0.8 & 2.5 & 1399.4 & 0.7437 & 703.43 & 0.0053647 \\
\hline 3 & 250 & 1 & 5 & 902.48 & 0.67887 & 831.97 & 0.0046286 \\
\hline 4 & 250 & 1.2 & 7.5 & 1271.5 & 0.59006 & 1271.5 & 0.00668 \\
\hline 5 & 500 & 0.6 & 2.5 & 592.07 & 0.57819 & 1570.8 & 0.0089547 \\
\hline 6 & 500 & 0.8 & 0 & 837.88 & 0.69996 & 837.88 & 0.0045756 \\
\hline 7 & 500 & 1 & 7.5 & 1508.9 & 0.71365 & 1508.9 & 0.71365 \\
\hline 8 & 500 & 1.2 & 5 & 882.57 & 0.79451 & 1131.1 & 0.0075965 \\
\hline 9 & 750 & 0.6 & 5 & 553.69 & 0.00428 & 587.26 & 0.0051214 \\
\hline 10 & 750 & 0.8 & 7.5 & 851.73 & 0.92068 & 851.73 & 0.00622596 \\
\hline 11 & 750 & 1 & 0 & 1103.1 & 0.4901 & 1103.1 & 0.0060613 \\
\hline 12 & 750 & 1.2 & 2.5 & 1688.1 & 0.99267 & 1571.2 & 0.99267 \\
\hline 13 & 1000 & 0.6 & 7.5 & 558.52 & 0.92068 & 558.52 & 0.92068 \\
\hline 14 & 1000 & 0.8 & 5 & 941.07 & 0.58262 & 941.07 & 0.0051077 \\
\hline 15 & 1000 & 1 & 2.5 & 1012.3 & 1.23314 & 1841.1 & 0.0092798 \\
\hline 16 & 1000 & 1.2 & 0 & 1893.7 & 1.197 & 1091.9 & 0.0069060 \\
\hline
\end{tabular}
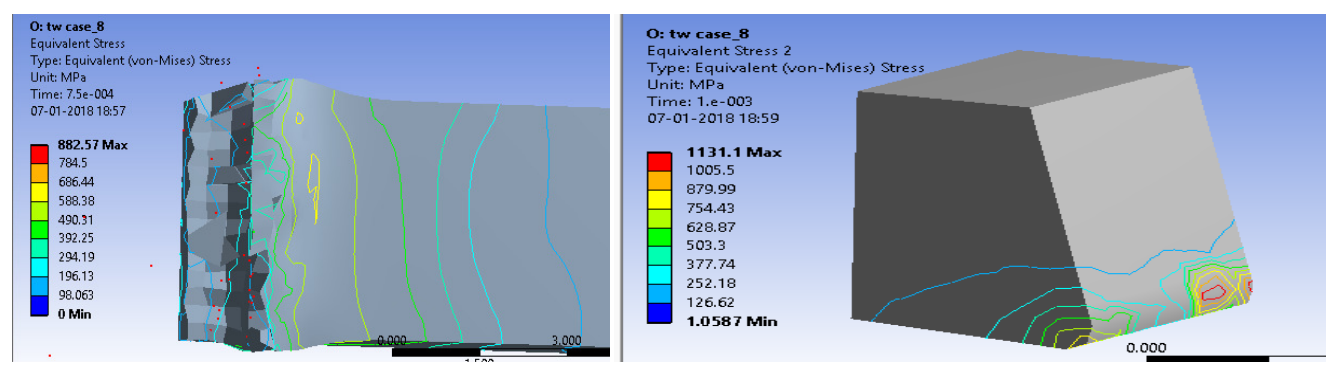

Fig. 3 Stress contour for work piece and tool in case 

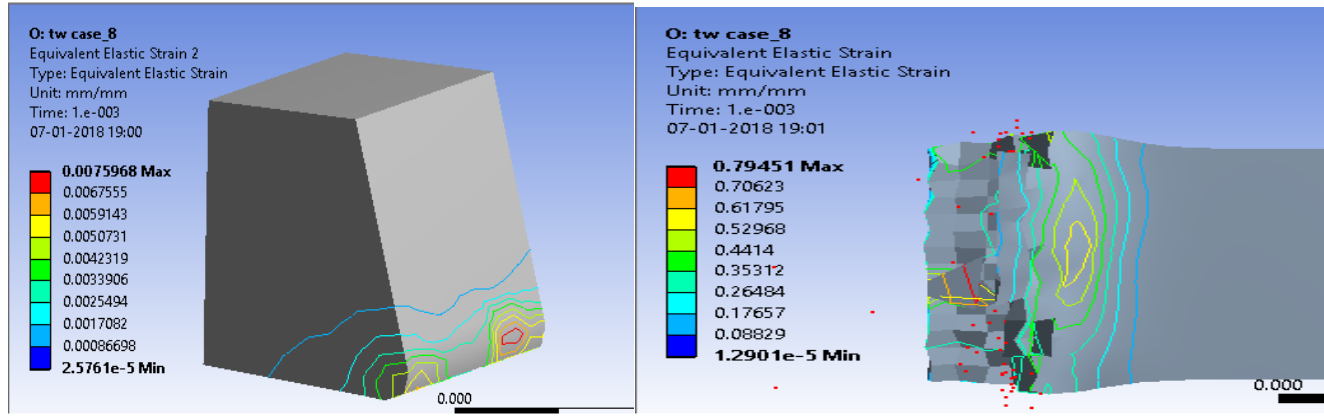

Fig. 4 Strain contour for work piece and tool in case

\subsection{Signal To Noise Ratio}

Minitab software is used for ANOVA analysis in this study. Summary table of three factors and their levels is presented in table3. Signal to noise ratio is simple technique to predict the effect of changing of factors according to their levels to find effect on product quality. In this study "smaller is better" option is adopted as quality indicator for $\mathrm{S} / \mathrm{N}$ ratio and means ratio. The response tables for $\mathrm{S} / \mathrm{N}$ ratio and mean are presented in table 6 and table 7.

Table 6 Response table for signal to noise ratio for work piece

\begin{tabular}{|c|c|c|c|}
\hline Level & cutting speed & Feed Rate & Rake Angle \\
\hline 1 & -59.84 & -55.3 & -60.03 \\
\hline 2 & -59.10 & -59.87 & -60.76 \\
\hline 3 & -59.02 & -60.91 & -58.09 \\
\hline 4 & -60.02 & -62.77 & -59.80 \\
\hline Delta & 0.92 & 7.65 & 2.66 \\
\hline Rank & $\mathbf{3}$ & $\mathbf{1}$ & $\mathbf{2}$ \\
\hline
\end{tabular}

Table 7. Response table for signal to noise ratio for tool

\begin{tabular}{|c|c|c|c|}
\hline Level & cutting speed & Feed Rate & Rake Angle \\
\hline 1 & -58.95 & -58.15 & -59.61 \\
\hline 2 & -61.76 & -58.37 & -62.52 \\
\hline 3 & -59.69 & -62.03 & -58.58 \\
\hline 4 & -60.12 & -61.96 & -59.80 \\
\hline Delta & 2.81 & 3.88 & 3.94 \\
\hline Rank & $\mathbf{3}$ & $\mathbf{2}$ & $\mathbf{1}$ \\
\hline
\end{tabular}

In this table represent factors importance ranking and it is clear that Feed Rate is most important factor in case of work piece and rake angle for cutting tool, which can reduce von-misses stress magnitude during cutting process. Best and worst cases from experiment factors and their levels are also presented in this study and were calculated from figure 5 and figure 6. 
International Journal of Recent Advances in Mechanical Engineering (IJMECH) Vol.7, No.1/2, May 2018

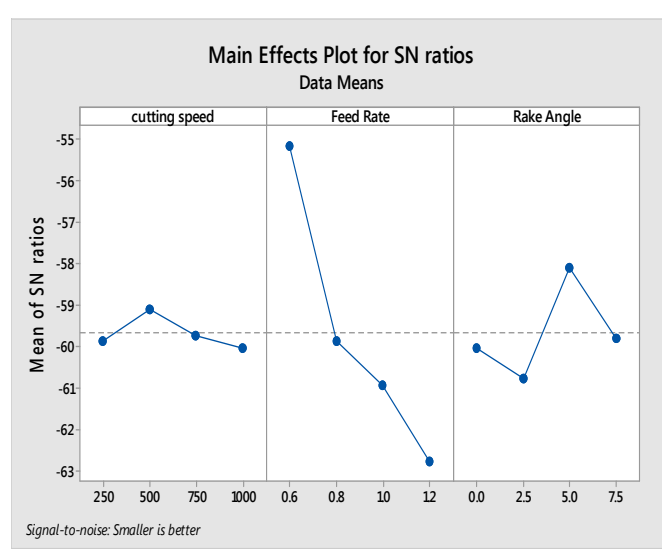

Fig.5 Data means for S/N ratios for work piece

Best case: A2 B1 C3

Worse Case: A1 B4 C2

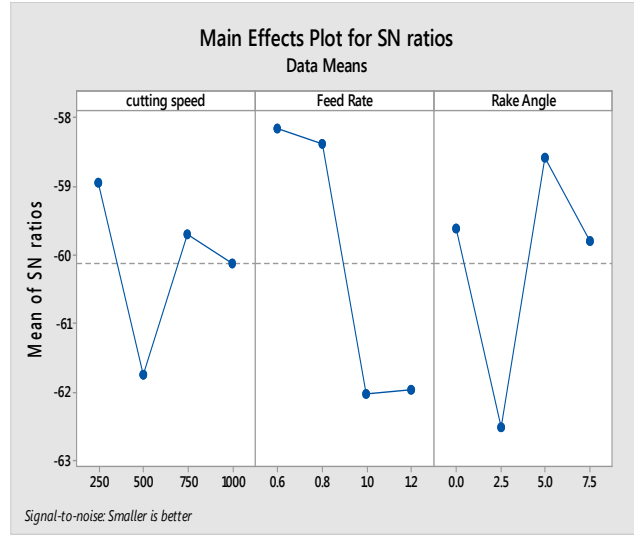

Fig.6 Data means for S/N ratios for tool

Best case: A1 B1 C3

Worse Case: A2 B3 C2

Here A, B and C represent factor cutting speed, feed rate and rake angle respectively. (Smaller is better)

Table $8 \mathrm{~S} / \mathrm{N}$ ratios for tool and Work piece

\begin{tabular}{|c|c|c|c|c|c|c|c|}
\hline Sr. No. & cutting speed & Feed Rate & Rake Angle & $\begin{array}{l}\text { Stress } \\
\text { in } \\
\text { Work } \\
\text { Piece }\end{array}$ & $\begin{array}{l}\text { Stress } \\
\text { in tool }\end{array}$ & $\begin{array}{l}\text { SN } \\
\text { ratio } \\
\text { for } \\
\text { Work } \\
\text { Piece } \\
\end{array}$ & $\begin{array}{l}\text { SN } \\
\text { ratio } \\
\text { for tool }\end{array}$ \\
\hline 1 & 250 & 0.6 & 0 & 578.77 & 827.6 & $\begin{array}{l}- \\
55.2501\end{array}$ & $-\overline{58.3564}$ \\
\hline 2 & 250 & 0.8 & 2.5 & 1399.4 & 703.43 & $\begin{array}{l}- \\
62.9188\end{array}$ & $\begin{array}{l}- \\
56.9444\end{array}$ \\
\hline 3 & 250 & 1 & 5 & 902.48 & 831.97 & $\begin{array}{l}- \\
59.1088\end{array}$ & $\begin{array}{l}- \\
58.4022\end{array}$ \\
\hline 4 & 250 & 1.2 & 7.5 & 1271.5 & 1271.5 & $\begin{array}{l}- \\
62.0863\end{array}$ & $\begin{array}{l}- \\
62.0863\end{array}$ \\
\hline 5 & 500 & 0.6 & 2.5 & 592.07 & 1570.8 & $\begin{array}{l}- \\
55.4475\end{array}$ & $\begin{array}{l}- \\
63.9224\end{array}$ \\
\hline 6 & 500 & 0.8 & 0 & 837.88 & 837.88 & $\begin{array}{l}- \\
58.4636\end{array}$ & $\begin{array}{l}- \\
58.4636\end{array}$ \\
\hline 7 & 500 & 1 & 7.5 & 1508.9 & 1508.9 & $\begin{array}{l}- \\
63.5732\end{array}$ & $\begin{array}{l}- \\
63.5732\end{array}$ \\
\hline 8 & 500 & 1.2 & 5 & 882.57 & 1131.1 & $\begin{array}{l}- \\
58.9150\end{array}$ & $\begin{array}{l}- \\
61.0700\end{array}$ \\
\hline 9 & 750 & 0.6 & 5 & 553.69 & 587.26 & $\begin{array}{l}- \\
54.8653\end{array}$ & $\begin{array}{l}- \\
55.3766\end{array}$ \\
\hline 10 & 750 & 0.8 & 7.5 & 851.73 & 851.73 & $\begin{array}{l}- \\
58.6060\end{array}$ & - \\
\hline
\end{tabular}


International Journal of Recent Advances in Mechanical Engineering (IJMECH) Vol.7, No.1/2, May 2018

\begin{tabular}{|c|c|c|c|c|c|c|c|}
\hline Sr. No. & cutting speed & Feed Rate & Rake Angle & $\begin{array}{c}\text { Stress } \\
\text { in } \\
\text { Work } \\
\text { Piece }\end{array}$ & $\begin{array}{l}\text { Stress } \\
\text { in tool }\end{array}$ & $\begin{array}{l}\text { SN } \\
\text { ratio } \\
\text { for } \\
\text { Work } \\
\text { Piece } \\
\end{array}$ & $\begin{array}{l}\mathrm{SN} \\
\text { ratio } \\
\text { for tool }\end{array}$ \\
\hline 11 & 750 & 1 & 0 & 1103.1 & 1103.1 & $\begin{array}{l}- \\
60.8523\end{array}$ & $\begin{array}{l}- \\
60.8523\end{array}$ \\
\hline 12 & 750 & 1.2 & 2.5 & 1688.1 & 1571.2 & $\begin{array}{l}- \\
64.5480\end{array}$ & $\begin{array}{l}- \\
63.9246\end{array}$ \\
\hline 13 & 1000 & 0.6 & 7.5 & 558.52 & 558.52 & $\begin{array}{l}- \\
54.9408\end{array}$ & -54.9408 \\
\hline 14 & 1000 & 0.8 & 5 & 941.07 & 941.07 & $\begin{array}{l}- \\
59.4724\end{array}$ & $\begin{array}{l}- \\
59.4724\end{array}$ \\
\hline 15 & 1000 & 1 & 2.5 & 1012.3 & 1841.1 & $\begin{array}{l}- \\
60.1062\end{array}$ & -65.3015 \\
\hline 16 & 1000 & 1.2 & 0 & 1893.7 & 1091.9 & $\begin{array}{l}- \\
65.5462\end{array}$ & $\begin{array}{l}- \\
60.7637\end{array}$ \\
\hline
\end{tabular}

\subsection{ANOVA ANALYSIS}

The analysis of variance is calculated for this study and results are shown in table 9 respectively. In ANOVA analysis F-Test is conduct to compare a model variance with a residual variance. $F$ value was calculated from a model mean square divided by residual mean square value. If $\mathrm{f}$ value was approaching to one means both variances were same, according $\mathrm{F}$ value highest was best to find critical input parameter. Table 9 list out one important result that $\mathrm{F}$ value for regression models are very high, than one and $\mathrm{P}$ value is very less (approx 0.0000) suggested that all cases were significant. From literature review various researchers found that if $p$ value was very small (less than 0.05) then the terms in the regression model have a significant effect to the responses.

ANOVA analysis is also tell that feed rate has very low $\mathrm{p}$ value than other factor in case stress in work piece and rake angle is most responsible for stress generation I cutting tool.

Table 9 Analysis of Variance (Square and 2 way) for Stress response

\begin{tabular}{|c|c|c|c|c|c|}
\hline Source & DF & Adj SS & Adj MS & F-Value & P-Value \\
\hline Model & 9 & 1988969 & 220997 & 2.26 & 1.62 \\
\hline Linear & 3 & 481395 & 160465 & 1.66 & 0.272 \\
\hline Cutting Speed & 1 & 42544 & 42544 & 0.44 & 0.531 \\
\hline Feed Rate & 1 & 371710 & 371710 & 3.86 & 0.097 \\
\hline Rake Angle & 1 & 67141 & 67141 & 0.70 & 0.436 \\
\hline Square & 3 & 61288 & 20429 & 0.21 & 0.885 \\
\hline Cutting speed*Cutting Speed & 1 & 18205 & 18205 & 0.19 & 0.679 \\
\hline Feed Rate* Feed Rate & 1 & 18086 & 18086 & 0.19 & 0.680 \\
\hline Rake Angle * Rake Angle & 1 & 24997 & 24997 & 0.26 & 0.629 \\
\hline 2-Way Interaction & 3 & 384528 & 128176 & 1.33 & 0.350 \\
\hline Cutting Speed*Feed Rate & 1 & 243369 & 243369 & 2.52 & 0.163 \\
\hline Cutting Speed*Rake Angle & 1 & 18799 & 18799 & 0.19 & 0.674 \\
\hline Feed Rate*Rake Angle & 1 & 122360 & 122360 & 1.27 & 0.303 \\
\hline Error & 6 & 578463 & 96410 & & \\
\hline Total & 15 & 2567432 & & & \\
\hline
\end{tabular}


International Journal of Recent Advances in Mechanical Engineering (IJMECH) Vol.7, No.1/2, May 2018

Table 10 Analysis of Variance (Square and 2 way) for Stress response for tool

\begin{tabular}{|c|c|c|c|c|c|}
\hline Source & DF & Adj SS & Adj MS & F-Value & P-Value \\
\hline Model & 9 & 1459055 & 162117 & 1.32 & 0.38 \\
\hline Linear & 3 & 527911 & 175970 & 1.43 & 0.32 \\
\hline Cutting Speed & 1 & 38866 & 38866 & 0.32 & 0.59 \\
\hline Feed Rate & 1 & 428572 & 428572 & 3.48 & 0.11 \\
\hline Rake Angle & 1 & 60473 & 60473 & 0.49 & 0.050 \\
\hline Square & 3 & 154283 & 51428 & 0.42 & 0.74 \\
\hline Cutting speed *Cutting Speed & 1 & 5 & 5 & 0.00 & 0.99 \\
\hline Feed Rate* Feed Rate & 1 & 74923 & 74923 & 0.61 & 0.46 \\
\hline Rake Angle * Rake Angle & 1 & 79355 & 79355 & 0.65 & 0.45 \\
\hline 2-Way Interaction & 3 & 729379 & 243126 & 1.98 & 0.21 \\
\hline Cutting Speed*Feed Rate & 1 & 163824 & 163824 & 1.33 & 0.29 \\
\hline Cutting Speed*Rake Angle & 1 & 480298 & 480298 & 3.91 & 0.096 \\
\hline Feed Rate*Rake Angle & 1 & 85257 & 85257 & 0.69 & 0.437 \\
\hline Error & 6 & 737927 & 122988 & & \\
\hline Total & 15 & 2196982 & & & \\
\hline
\end{tabular}

Model equations for von-miss stress are presented in table 11 linear and 2 way ANOVA analysis with model equations.

Table 11 Model summary for ANOVA analysis

\begin{tabular}{|c|c|c|c|c|}
\hline & S & R-sq & R-sq(adj) & R-sq(pred) \\
\hline Work piece & 310.500 & $77.47 \%$ & $43.67 \%$ & $0.00 \%$ \\
\hline Tool & 350.500 & $66.41 \%$ & $16.03 \%$ & $0.00 \%$ \\
\hline
\end{tabular}

Model Equation

Regression Equation

Stress in Work Piece $=521-3.70$ cutting speed +1468 Feed Rate +250 Rake Angle +0.00054 cutting speed*cutting speed -841 Feed Rate*Feed Rate +6.3 Rake Angle*Rake Angle +3.33 cutting speed*Feed Rate - 0.074 cutting speed*Rake Angle - 236 Feed Rate* Rake Angle

Stress in tool $=2306-3060$ Feed Rate +0.49 cutting speed -201 Rake Angle 15 Feed Rate*Feed Rate - 0.00109 cutting speed*cutting spetd - 11.3 Rake Angle*Rake Angle +2.73 Feed Rate*cutting speed +467 Feed Rate*Rake Angle - 0.157 cutting speed*Rake Angle

The adequacy of regression models shall be inspected to confirm that the all models have extracted all relevant information from all simulated cases. If regression equations results were adequate than the distribution of residuals should be normal distribution. For normality test, the Hypotheses are listed below

A. Null Hypothesis: the residual data should follow normal distribution

B. Alternative Hypothesis: the residual data does not follow a normal distribution Normal

probability figures for all responses were shown in figure 7 and figure 8 . 


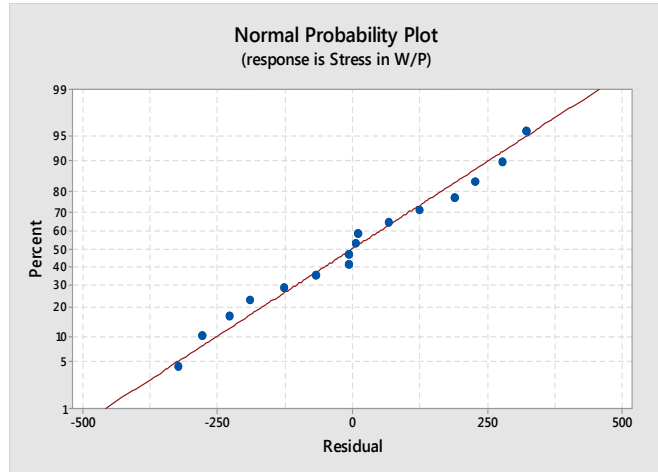

Fig. 7Normal probability for Stress in work piece

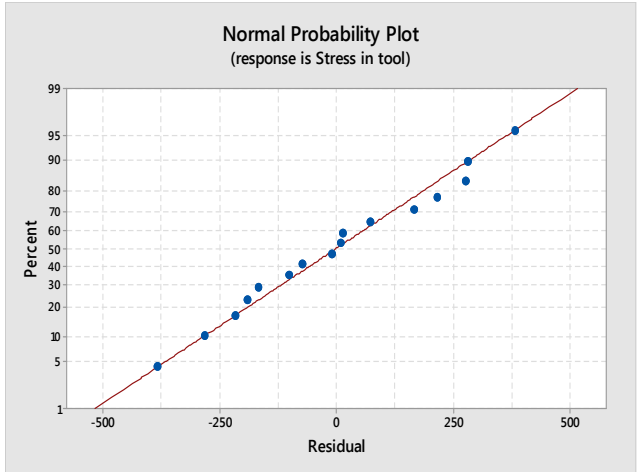

Fig. 8 Normal probability for Stress in tool

\subsection{Artificial NeURal Network}

In this study ANN method is also used for prediction of outcome data gained by experimental work. ANN is advanced method to predict model equation generated by using experiments data. In present section both responses are predicted using ANN method. MATLAB software is used to solve ANN method for stress. $60 \%$ experiments are used for training, $20 \%$ are used to validate that the network is generalizing and the last $20 \%$ are used as a completely independent test of network generalization.

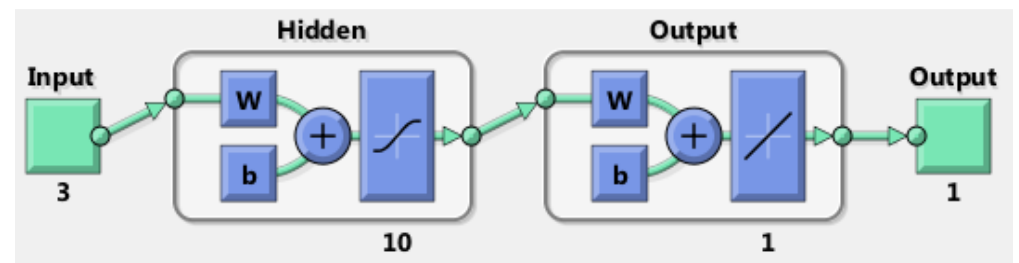

Figure 9. Function Fitting Neural Network Diagram

Fig.9.Functions Fitting Neural Network Diagram for MRR shows an opened window of the network during training. This window displays training progress and allows the user to interrupt training at any point by clicking stop training.

Figure 10 represent the training, validation, and testing data. The dashed line in each plot represents the perfect result - outputs $=$ targets It is observed that the output tracks the targets very well for training $(\mathrm{R}$-value $=0.9906)$, validation $(\mathrm{R}$-value $=1)$, and testing $(\mathrm{R}$-value $=1)$. These values can be equivalent to a total response of $\mathrm{R}$-value $=0.8774$ for stress generation in work piece and training $(\mathrm{R}$-value $=1)$, validation $(\mathrm{R}$-value $=1)$, and testing $(\mathrm{R}$-value $=1)$. These values can be equivalent to a total response of $\mathrm{R}$-value $=0.96036$ for stress generation in tool.In this case, the output response is satisfactory, and simulation can be used for entering new inputs. The results of this study indicated high correlation coefficient (R-value) between the measured and predicted output variables, reaching up to 0.9. Therefore, the model developed in this work has an acceptable generalization capability and accuracy. As a result, the neural network modeling could effectively simulate and predict the performance of response data for stress develop in tool and work piece. Prediction values are presented in table 12. 

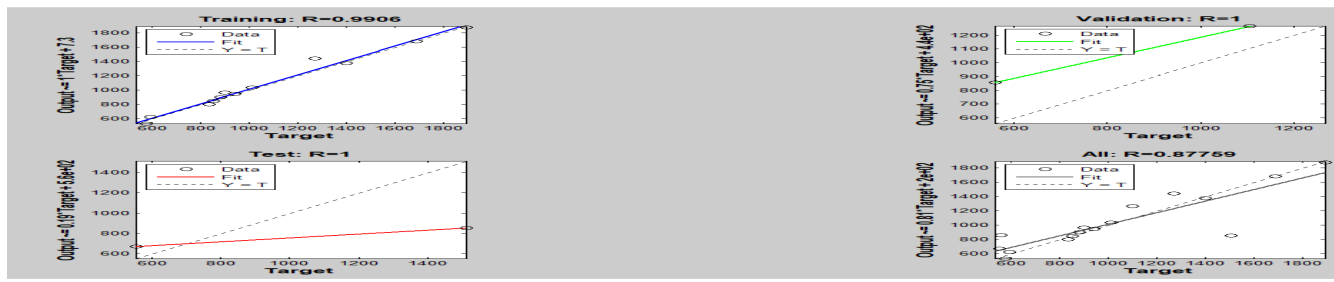

Figure 10. Regression Results for work piece
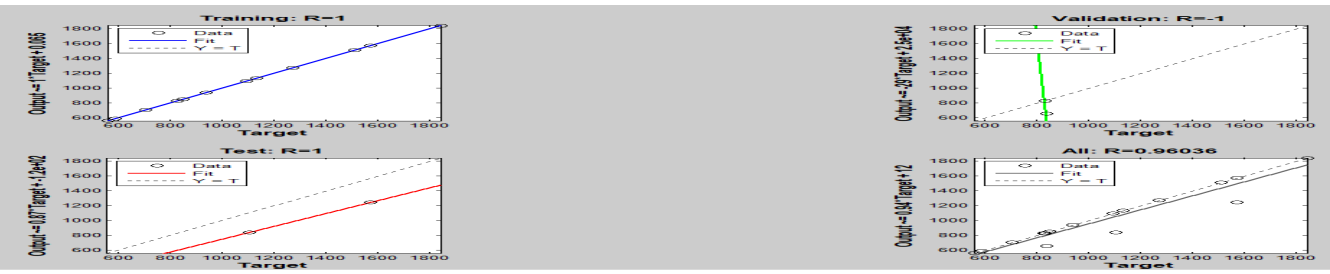

Figure 11. Regression Results for tool stress

Table12. ANN Prediction results

\begin{tabular}{|c|c|c|c|c|c|c|c|}
\hline Sr. No. & $\begin{array}{c}\text { cutting } \\
\text { speed }\end{array}$ & $\begin{array}{c}\text { Feed } \\
\text { Rate }\end{array}$ & $\begin{array}{c}\text { Rake } \\
\text { Angle }\end{array}$ & $\begin{array}{c}\text { Stress } \\
\text { in tool }\end{array}$ & $\begin{array}{c}\text { Stress } \\
\text { in } \\
\text { Work } \\
\text { piece }\end{array}$ & $\begin{array}{c}\text { Stress in tool } \\
\text { (Predicated) }\end{array}$ & $\begin{array}{c}\text { Stress in work } \\
\text { piece } \\
\text { (Predicated) }\end{array}$ \\
\hline 1 & 250 & 0.6 & 0 & 827.6 & 578.77 & 827.62 & 531.70 \\
\hline 2 & 250 & 0.8 & 2.5 & 703.43 & 1399.4 & 703.45 & 1376.04 \\
\hline 3 & 250 & 1 & 5 & 831.97 & 902.48 & 827.60 & 963.56 \\
\hline 4 & 250 & 1.2 & 7.5 & 1271.5 & 1271.5 & 1271.51 & 1441.06 \\
\hline 5 & 500 & 0.6 & 2.5 & 1570.8 & 592.07 & 1570.812 & 624.84 \\
\hline 6 & 500 & 0.8 & 0 & 837.88 & 837.88 & 655.90 & 801.03 \\
\hline 7 & 500 & 1 & 7.5 & 1508.9 & 1508.9 & 1508.916 & 854.16 \\
\hline 8 & 500 & 1.2 & 5 & 1131.1 & 882.57 & 1131.04 & 899.41 \\
\hline 9 & 750 & 0.6 & 5 & 587.26 & 553.69 & 587.28 & 670.09 \\
\hline 10 & 750 & 0.8 & 7.5 & 851.73 & 851.73 & 851.7 & 847.50 \\
\hline 11 & 750 & 1 & 0 & 1103.1 & 1103.1 & 838.58 & 1265.18 \\
\hline 12 & 750 & 1.2 & 2.5 & 1571.2 & 1688.1 & 1245.03 & 1686.77 \\
\hline 13 & 1000 & 0.6 & 7.5 & 558.52 & 558.52 & 558.53 & 858.085 \\
\hline 14 & 1000 & 0.8 & 5 & 941.07 & 941.07 & 941.09 & 946.794 \\
\hline 15 & 1000 & 1 & 2.5 & 1841.1 & 1012.3 & 1841.09 & 1033.37 \\
\hline 16 & 1000 & 1.2 & 0 & 1091.9 & 1893.7 & 1092.31 & 1876.49 \\
\hline
\end{tabular}

\section{CONCLUSION}

The aim of this study is to try to balance among response results and FEM simulation results for single point cutting machining process. This study utilizes L16 orthogonal array for FEM based data analysis. In this study Analysis of variance (ANOVA), and linear regression analysis is main key techniques to show response and factor relations strongly with each other. Main results are summarized as follows:

1. Signal to noise ratio predict a rank for most responsible factors rack angle is most responsible for tool wear.

2. Model equations for stress response was predict accurately with Minitab software and show $90 \%$ good prediction for responses and can be used by any cutting based machining process manufacturer. 
3. Stress in tool and work piece also was predicted by ANN approach. This paper has successfully established new process model to predict the stress in different practical applications, values of the process parameters can be controlled better if the process models are employed in different industrial applications

\section{REFERENCES}

[1] M.Mahnama, M.R Movahhedy 2012, Application of FEM Simulation of chip formation to stability Analysis in orthogonal cutting Process, Journal of Manufacturing Processes Vol.188-194.

[2] J.Lorentzon, N.Jarvstrat, B.L Josefson, 2009, Modeling chip formation of alloy 718, Journal of Material Processing Technology vol. 4645-4653.

[3] C.Dumitras, I.Cozminca, C.Ungureanu, M.Mihailide, Oct 2008, A Finite Element Analysis of the cutting Insert Geometry Influence in Machining Hard Material, Machine Tools and Cutting Tool Design Department, Technical University, Gh.Asachi, Romania.

[4] E.Uhimann, M.Graf Von der Schulenburg, R.Zettier, 2007,Finite Element Modeling and Cutting Simulation of Inconel 718, Institute of Machine Tools and Factory Management, Techische Universitat, Germany, Vol.56/1/2007.

[5] S.H Rathod, Mohd. Razik, 2013, Review Study on Finite Element Analysis of Single Point Cutting Tool, International Journal of Engineering Research and Development, Vol. 9, PP.11-14.

[6] L.J Xie, J.Schmidt, C.Schmidt, F.Biesinger, 2005, 2D FEM estimate of tool wear in turning operation, institute for werkstoffkunde, Germany.

[7] Dr.Maan Aabid Tawfiq, Suha Kareem Shahab,2006, A finite element analysis of orthogonal machining using different tool edge geometries, Eng. \& technology Vol.25.

[8] J.S.Strenkowski, J.T Caroll, A finite element model of orthogonal metal cutting, J Engrg Ind. 107 (1985) 349-354.

[9] T.D Marusich, M.Ortiz, Modeling and Simulation of high Speed, Machining, Int.J.Numer. Meth. Engrg 38(1995) 3675-3694.

[10] T.J.R Hughes, The Finite Element Method, Linear Static and Dynamic Finite Element Analysis. Prentice Hall. 1987.

[11] A Mahamani, (2014), Influence of Process Parameters on Cutting Force and SurfaceRoughness During Turning of AA2219-TiB2/ZrB2 In-situ Metal Matrix Composites, Procedia Materials Science voi 6 , pp- $1178-1186$

[12] Arshad Noor Siddiqueea,, Zahid A. Khana, Pankul Goel, Mukesh Kumar, Gaurav Agarwal,(2014), Optimization of Deep Drilling Process Parameters of AISI 321 Steel using Taguchi Method, Procedia Materials Science vol 6 pp-1217 - 1225

[13] Mathias Agmell,, Aylin Ahadia, Jan-Eric Ståhl, (2013), The Link Between Plasticity Parameters and Process Parameters in Orthogonal Cutting, Procedia CIRP vol8, pp 224 - 229

[14] J Frederik Zanger, Nikolay Boev, Volker Schulze, 2015, Novel approach for 3D Simulation of a Cutting Process with Adaptive Remeshing Technique, Procedia CIRP vol 31, pp-88 - 93

[15] T.Senthil Kumar1, G.Mahadevan2, T.R.Vikraman, 2014, Evalution of Surface Finish on Machining Of Mild Steel Using High Speed Steel Tool in Lathe with Normal Coolant (Or) Nano Material Added Coolant, Journal of Mechanical and Civil Engineering (IOSR-JMCE), Vol 11, Issue 3 Ver. V (MayJun. 2014), pp 01-09

[16] Puneet Saini *, Shanti Parkash**, Devender Choudhary, 2014 Experimental Investigation of Machining Parameters For Surface Roughness In High Speed CNC Turning of EN-24 Alloy Steel Using Response Surface Journal of Mechanical and Civil Engineering (IOSR-JMCE), Vol 5, Issue 5 Ver.7 (May- Jun. 2014), pp 153-160 